\title{
Gregório de Matos - Cinco Poemas em Inglês
}

\author{
John Milton
}

\section{The Poet Defines His City}

If you ask me, this city

is made up of two ffs:

one fuck, the other filch.

Its name has been rewritten

and he who renamed

it with two ffs explained

that it's perfectly mixed,

it's digested and fixed:

as two effs it deserves,

and whoever might observe

at what here abounds

will say that for this town

the two effs we should reserve.

If with two ffs it is writ

this our town of Bahia,

with its spelling somewhat queer, 
MILTON, John. Gregório de Matos - Cinco Poemas em Inglês

then great harm is set:

And I want to make a bet

and lose a crown

that this will pervert the town

if filching and fucking are not

the ffs that Bahia's already got.

This surmise I think I may

prove as quickly as an enigma.

Five letters has Bahia

which are $\mathrm{B}-\mathrm{A}-\mathrm{H}-\mathrm{I}-\mathrm{A}$

so no one thinks they can say

it has two ffs

It doesn't have either,

unless it really does own

those of the town

one filch, fuck the other. 


\section{Define a Sua Cidade}

De dois ff se compõe esta cidade a meu ver: um furtar, outro foder. Recopilou-se o direito, e quem o recopilou com dous ff o explicou por estar feito, e bem feito: por bem digesto, e colheito só com dous ff o expõe, e assim quem os olhos põe no trato, que aqui se encerra, há de dizer que esta terra de dous ff se compõe. Se de dous ff composta está a nossa Bahia, errada a ortografia, a grande dano está posta: eu quero fazer aposta e quero um tostão perder, que isso a há de perverter, se o furtar e o foder bem não são os ff que tem esta cidade ao meu ver. Provo a conjetura já, prontamente como um brinco: Bahia tem letras cinco 
MILTON, John. Gregório de Matos - Cinco Poemas em Inglês

que são $\mathrm{B}-\mathrm{A}-\mathrm{H}-\mathrm{I}-\mathrm{A}$ :

logo ninguém me dirá

que dous ff chega a ter,

pois nenhum contém sequer,

salvo se em boa verdade

são os ff da cidade

um furtar, outro foder. 
The Poet Complains that the World is Wrong, and Finds He Has a Difficult TaSk to Improve It

Heavy and weary am I on earth, My efforts blocked by a huge great load, And as I walk along an unknown road The weight grows and I lose my worth.

The solution is to follow the shit, And wherever I see the steps of the rest, I know the beasts together are always the best, Rather than those who have all the wit. To be among the insane is no easy feat, And he who thinks he knows is mistaken.

Unaware of the harm he did along the route, The prudent man must be silent And it's far better in this sea of deceit To be mad with the rest than to be intelligent. 
MILTON, John. Gregório de Matos - Cinco Poemas em Inglês

Queixa-se o Poeta em que o Mundo val Errado, e Querendo

EmendÁlo O Tem por Empreza Dificultosa

Carregado de mim ando no mundo,

E o grande peso embarga-me as passadas,

Que como ando por vias desusadas,

Faço o peso crescer, e vou-me ao fundo.

O remédio será seguir o imundo

Caminho, onde dos mais vejo as pisadas,

Que as bestas andam juntas mais ornadas,

Do que anda só o engenho mais profundo.

Não é fácil viver entre os insanos,

Erra, quem presumir, que sabe tudo,

Se o atalho não soube dos seus danos.

prudente varão há de ser mudo,

Que é melhor neste mundo em mar de enganos

Ser louco cos demais, que ser sisudo. 
The Poet Describes what the City of Bahia was Really Like at that Time from the Most Embroiled to the Less Confusing

A great counsellor in every place,

Who wants to govern our hut and vine

And they can't even rule their own house

But know how to govern human kind.

At each door a nosey snout

Who surveys, listens, scans and scours

The entire life of the neighbour

To take it to the square and shout it out,

Scores of mulattoes all immodest,

Brought by their own feet the nobs

Since their palms are much the greasier.

In the markets high rates of interest,

All those are poor who do not rob.

This is all the city of Bahia. 
MILTON, John. Gregório de Matos - Cinco Poemas em Inglês

DescreVo que era REALMente NAQUELE TEMPO A CIDADE DA BAHIA DE MAIS ENREDADA POR MENOS CONFUSA

A cada canto um grande conselheiro,

que nos quer governar cabana, e vinha, não sabem governar sua cozinha,

e podem governar o mundo inteiro.

Em cada porta um freqüentado olheiro, que a vida do vizinho, e da vizinha pesquisa, escuta, espreita, e esquadrinha, para a levar à Praça, e ao Terreiro.

Muitos mulatos desavergonhados, trazidos pelos pés os homens nobres, posta nas palmas toda a picardia.

Estupendas usuras nos mercados, todos, os que não furtam, muito pobres, e eis aqui a cidade da Bahia. 
Contemplating the Things of the World from his Retreat, he AttaCkS IT WITH hIS Fury, LIKE ONE that has EsCaped from

a STORM by SWIMMING

In this world the rich are those who swipe:

The cleanest have most dust upon their grapes:

With their tongues the low put the nobs upon the rope:

And the greatest swindler will have a fine cape.

The cheat will always the great ones dupe:

He who snatches and seizes will always cope:

He who speaks least will most gripe:

He who has most money will become Pope.

The lowly flower appears just like a tulip:

Yesterday a plane in his hand, today a pipe:

The less concerned he is, the more he dupes.

This troop of tramps sends me to the jakes,

And I say no more, for the Muse gives hopes

For apes and ipes and opes and upes. 
MILTON, John. Gregório de Matos - Cinco Poemas em Inglês

CONTEMPLANDO NAS COUSAS DO MUNDO DESDE O SEU RETIRO, LHE ATIRA COM A SEU APAGE, COMO QUEM A NADO ESCAPOU DA TROMENTA

Neste mundo é mais rico o que mais rapa:

Quem mais limpo se faz, tem mais carepa:

Com sua língua ao nobre o vil decepa:

Velhaco maior sempre tem capa.

Mostra o patife da nobreza o mapa:

Quem tem mão de agarrar, ligeiro trepa;

Quem menos falar pode, mais increpa:

Quem dinheiro tiver, pode ser Papa.

A flor baixa se inculca por Tulipa;

Bengala hoje na mão, ontem garlopa:

Mais isento se mostra o que mais chupa.

Para a tropa do trapo vazo a tripa,

E mais não digo, porque a Musa topa

Em apa, epa, ipa, opa, upa 
On the Day the Poet Decided to Court a Nun in the Same

Convent, Her Bed Caught Fire, and, Trying to Put it Out, She

BURNT HER HAND

Yesterday I was ready to love you, and right

Inside me felt such a great desire,

That burning in me such an amorous fire,

Your cell by Love was set alight.

You, sleeping without a care,

At the sound of crackling jumped out of bed,

Seeing burn a soul that to you is devoted,

Moved by pity and not by prayer,

You put in the fire your snow white

Hand, which, to free itself from the fire repairs,

As this would be a very brief fight.

But alas! how can the hand dare,

If snow Love can set alight,

To doubt the Love that in the snow does flare. 
MILTON, John. Gregório de Matos - Cinco Poemas em Inglês

NO DIA EM QUE O POETA EMPRENDEO GALANTEAR HUA FREYRA DO MESMO CONVENTO, SE LHE PEGOU O FOGO NA CAMA, E INDO APAGAR-LO, QUEYMO UMA MÃO

Ontem a amar-vos me dispus, e logo Senti dentro de mim tão grande chama, Que vendo arder-me na amorosa flama, Tocou Amor na vossa cela o fogo. Dormindo vós com todo o desafogo Ao som do repicar saltais da cama, E vendo arder uma alma, que vos ama, Movida da piedade, e não do rogo

Fizestes aplicar ao fogo a neve

De uma mão branca, que livrar-se entende Da chama, de quem foi despojo breve. Mas ai! que se na neve Amor se acende, Como de si esquecida a mão se atreve A apagar, o que Amor na neve incende. 